\title{
MODEL PENGUKURAN KEMAMPUAN KEUANGAN DAERAH MELALUI KEMANDIRIAN FISKAL DAN DERAJAT EKONOMI UNTUK MENINGKATKAN AKUNTABILITAS DAN TRANSPARANSI ANGGARAN PENDAPATAN DAN BELANJA (APBD) PEMERINTAH KABUPATEN SUMBA BARAT
}

\author{
Deasy Susana R. Ndaparoka ${ }^{1 *}$, Alfred T. Rantelobo ${ }^{2,}$ Selfesina Samadara ${ }^{3}$ \\ ${ }_{1,2,3}$ Politeknik Negeri Kupang \\ * deasy_susana@yahoo.com
}

\begin{abstract}
Abstrak
Pembangunan ekonomi sebagai salah satu prioritas pembangunan nasional bertujuan mempercepat pemulihan ekonomi serta memperkuat landasan pembangunan ekonomi berkelanjutan dan berkeadilan berdasarkan sistem kerakyatan. Otonomi fiskal merupakan aspek penting dalam menggambarkan kemampuan daerah dalam meningkatkan Pendapatan Asli Daerah (PAD). Harus diakui bahwa derajat otonomi fiskal daerah di Indonesia masih rendah dan belum mampu membiayai pengeluaran rutinnya. Otonomi daerah bisa diwujudkan hanya apabila disertai keuangan yang efektif. Penelitian ini untuk menemukan Model Pengukuran Kemampuan Keuangan Daerah Melalui Kemandirian Fiskal Dan Derajat Ekonomi Untuk Meningkatkan Akuntabilitas Dan Transparansi Anggaran Pendapatan Dan Belanja (APBD) Pemerintah Kabupaten Sumba Barat. Hasil penelitian menunjukkan tingkat kemampuan keuangan daerah dan konstribusi PAD terhadap APBD Kabupaten Sumba Barat tahun 2011-2015 dianggap masih kurang dan relatif kecil. Pemerintah Kabupaten Sumba Barat perlu mengoptimalisasi pengelolaan pendapatan daerah dengan mensinergikan program intensifikasi dan ekstensifikasi sumber pendapatan daerah sesuai potensi dan kewenangan berdasarkan ketentuan peraturan perundangan dengan mengedepankan aspek keadilan dan kemampuan masyarakat.
\end{abstract}

Kata kunci: Kemampuan keuangan daerah, kemandirian fiskal, derajat ekonomi, akuntabilitas, transparansi, anggaran pendapatan dan belanja daerah.

KENDAHULUAN
Kemampuan pemerintah daerah
dalam mengelola keuangan tercermin dalam
Anggaran Pendapatan Belanja Daerah
(APBD) yang menggambarkan kemampuan
pemerintah daerah dalam membiayai kegiatan
pelaksanaan tugas pembangunan, serta
pemerataan dan keadilan dengan
mengembangkan seluruh potensi yang dimiliki
oleh masing-masing daerah. Salah satu
alasan penyelenggaraan otonomi daerah
adalah agar pembangunan di daerah berjalan
seiring dengan pembangunan pusat. Ini
merupakan bentuk koreksi atas pelaksanaan
pembangunan ekonomi yang selama ini
menitik beratkan pembangunan di pusat dan
kurang memperhatikan perkembangan
pembangunan daerah. Dengan kebijakan yang
sentralistik ini menyebabkan terjadinya
disparitas dan ketidakseimbangan
pelaksanaan pembangunan di pusat dan
daerah. Akibatnya hampir seluruh potensi

ekonomi di daerah tersedot ke pusat sehingga daerah tidak mampu berkembang secara mamadai. Jadi dengan otonomi daerah terkandung maksud untuk memeperbaiki kekeliruan selama ini dengan cara memberikan peluang kepada daerah untuk mendapatkan dana lebih besar dan kebebasan untuk mengelolanya sendiri. Dalam sistem otonomi bertingkat berdasarkan UU No. 5 tahun 1974, rendahnya pendapatan asli daerah (PAD) sebagai sumber pembiayaan pembangunan atau realisasi APBD bukan merupakan masalah besar, karena pemerintah pusat mengalokasikan dana untuk belanja pegawai, pengeluaran rutin dan pembangunan daerah. Istilah "bukan masalah besar" tersebut merujuk pada kenyataan bahwa otonomi yang dikembangkan, diimplementasikan dengan penyerahan urusan pusat pada daerah.

Munculnya Undang-undang nomor 22 tahun 1999 tentang Pemerintahan. Daerah dan Undang-undang nomor 25 tahun 1999 
tentang Perimbangan Keuangan Antara Pemerintah Pusat dan Daerah, adalah jawaban atas permasalahan tersebut, Dengan demikian ideologi politik dan struktur pemerintahan negara akan lebih bersifat desentralisasi dibanding dengan struktur pemerintahan sebelumnya yang bersifat sentralisasi. Maka sudah saatnya bagi pemerintah Indonesia untuk melaksanakan sistem pemerintahan yang meletakkan peranan pemerintah daerah pada posisi yang sangat krusial dalam meningkatkan kesejahteraan warganya. Pemberian kewenangan yang luas, nyata dan bertanggungjawab yang tersirat dalam perundangan tersebut, adalah pencerminan proses demokratisasi dalam pelaksanaan otonomi daerah untuk membantu pernerintah pusat dalam menyelenggarakan pemerintahan di daerah dengan titik berat kepada pemerintah kabupaten. Secara yuridis, pelaksanaan otonomi yang luas dan nyata tersebut bukan merupakan kelanjutan. Tetapi secara faktual empiris, merupakan kesinambungan dari pelaksanaan otonomi daerah berdasarkan UU nomor 5 tahun 1974 dan bahkan peraturan sebelumnya. Jadi tujuan kebijakan desentralisasi adalah : mewujudkan keadilan antara kemampuan dan hak daerah; peningkatan pendapatan asli daerah dan pengurangan subsidi dari pusat; mendorong pembangunan daerah sesuai dengan aspirasi masing-masing daerah.

Desentralisasi fiskal diartikan sebagai

penyerahan fungsi pengeluaran dan pendapatan dari pemerintah pusat ke pemerintah daerah (Syahrudin, 2006). Dengan adanya desentralisasi fiskal ini terdapat pemisahan yang jelas dan tegas dalam urusan keuangan antara pemerintah pusat dan daerah. Liu (2011) dan Syahrudin (2006) telah membuktikan bahwa desentralisasi fiskal menghasilkan manfaat ekonomi bagi negara seperti peningkatan tingkat pertumbuhan, peningkatan efektifitas dan efisiensi pengelolaan sumberdaya serta peningkatan partisipasi masyarakat dalam pengambilan keputusan (Liu, 2011). Giannoni (2002) menemukan bahwa desentralisasi fiskal meningkatkan kualitas pembuatan keputusan dengan menggunakan informasi lokal, meningkatkan akuntabilitas dan meningkatkan kemampuan respon terhadap kebutuhan dan kondisi lokal (Giannoni, 2002). Disamping itu Moisiu (2013) menyatakan bahwa pemerintah lokal lebih responsif terhadap warga negaranya dibanding pemerintah pusat sehingga keputusan yang diambil lebih merefleksikan kebutuhan dan keinginan rakyat. Konsisten dengan pendapat ini, Mills
(1994) menjelaskan bahwa desentralisasi akan membawa pemerintah lebih dekat dengan rakyat sehingga partisipasi mereka juga akan lebih besar.

Otonomi Daerah membawa

konsekuensi pada pemerintah daerah untuk mengatur dan mengurusi kepentingan masyarakat setempat menurut prakarsa sendiri, berdasarkan aspirasi masyarakat sesuai dengan peraturan perundangundangan. Dalam menjalankan otonomi daerah, Pemerintah Daerah dituntut untuk menjalankan roda pemerintahan yang efektif, efisien, dan mampu mendukung peran masyarakat dalam meningkatkan pemerataan dan keadilan dengan mengembangkan seluruh potensi yang dimiliki oleh masingmasing daerah. Keberhasilan otonomi daerah tidak terlepas dari kemampuan dalam bidang keuangan. Oleh karena itu pemerintah daerah diharapkan dapat mengembangkan potensi daerahnya sendiri dan menggali sumber dana yang ada dan potensial guna mewujudkan peningkatan kesejahteraan warga masyarakatnya. Akibatnya mekanisme pembiayaan pelaksanaan otonomi daerah berubah yaitu diutamakan semaksimal mungkin berasal dari potensi penerimaan asli daerah baik melalui pajak daerah, retribusi daerah maupun dari laba Badan Usaha Milik Daerah (BUMD) dan penerimaan lain yang dianggap sah serta potensi penerimaan lain yang masih belum terjangkau oleh Pendapatan Asli Daerah (PAD).

\section{METODE PENELITIAN}

Penelitian ini menggunakan metode deskriptif dimana akan diuraikan dan dianalisis permasalahan penelitian. Pendekatan yang dipergunakan dalam penelitian ini adalah pendekatan kualitatif dengan pendalaman fakta melalui pendekatan kuantitatif yang merupakan suatu paradigma penelitian untuk mendeskripsikan peristiwa, perilaku orang atau suatu keadaan pada tempat tertentu secara rinci dan mendalam dalam bentuk narasi. Penelitian ini dilaksanakan di Kabupaten Sumba Barat dengan memperoleh data melalui Dinas Pendapatan Daerah (Dispenda) Kabupaten Sumba Barat, dan Badan Pusat Statistik (BPS) Kabupaten Sumba Barat. Peneliti berusaha memotret peristiwa dan kejadian yang menjadi pusat perhatiannya, kemudian menggambarkan atau melukiskannya sebagaimana adanya, sehingga pemanfaatan temuan penelitian ini berlaku pada saat itu pula yang belum tentu relevan bila digunakan untuk waktu yang akan datang. Tidak menuntut adanya perlakuan atau manipulasi variabel, karena gejala dan 
peristiwanya telah ada dan peneliti tinggal mendeskripsikannya. Jenis penelitian ini adalah kuantitatif kualitatif (mixed). Metode kualitatif dan kuantitatif dapat digabungkan bahkan mempunyai kelebihan-kelebihan jika dibandingkan dengan menggunakan satu metode saja. Peneliti dapat menggunakan kekuatan-kekuatan metode tambahan untuk mengatasi kelemahan metode lainnya. Selain itu, penggunaan metode lebih dari satu dimaksudkan sebagai sarana konfirmasi, jika hanya dengan satu metode peneliti menganggap temuan riset kurang valid, maka perlu ada metode lain untuk konfimasi lebih lanjut sehingga menghasilkan temuan-temuan riset yang lebih valid.

Dalam melakukan pengumpulan data, penulis menggunakan teknik studi lapang (field research) dengan menghimpun data primer untuk mendukung penelitian serta melakukan pencarian data sekunder, baik yang berupa catatan-catatan, laporan-laporan, dokumendokumen, maupun literatur yang ada hubungannya dengan masalah penelitian ini. Data primer adalah data yang diperoleh langsung dari sumbernya, baik orang-orang yang telah ditetapkan menjadi informan maupun kondisi riil yang didapat langsung di lokasi penelitian dengan cara melakukan observasi dan wawancara. Dalam rangka pengumpulan data ini, penulis menggunakan teknik pengumpulan data dengan cara dokumentasi data keuangan pemerintah daerah setempat.

Peneliti juga menggunakan teknik studi kepustakaan (library research) melalui teksteks tertulis maupun soft copy seperti buku ebook artikel-artikel dalam jurnal, laporan, makalah, tesis dan skripsi yang dipublikasikan pemerintah dan lain-lain seperti dokumendokumen yang berupa data statistik, arsip, gambar, maupun grafik dari Pemerintah Daerah, perusahaan ataupun sumber lainnya yang valid, seperti Laporan Realisasi Anggaran, Anggaran Pendapatan dan Belanja Daerah, Laporan Keterangan Pertanggungjawaban Pemerintah Kabupaten, dan sebagainya.

\section{HASIL DAN PEMBAHASAN}

Pemerintah Daerah diberi kewenangan yang lebih besar untuk mewujudkan kemandirian keuangan melalui desentralisasi fiskal yang diatur dengan peraturan perundang-undangan untuk pelaksanaan otonomi daerah dan penguatan kapasitas fiskal daerah. Beberapa peraturan yang terkait langsung dengan hal tersebut adalah Undang-Undang Nomor 32 Tahun 2004 tentang Pemerintahan Daerah, UndangUndang Nomor 33 Tahun 2004 tentang Perimbangan Keuangan antara Pemerintah Pusat dan Daerah. Untuk meningkatkan kualitas pengelolaan keuangan daerah dilakuan Analisis rasio keuangan terhadap realisasi APBD. Disamping meningkatkan kuantitas pengelolaan keuangan daerah, analisis rasio terhadap realisasi APBD juga dapat digunakan sebagai alat untuk menilai efektivitas pelaksanaan otonomi daerah. Sebab kebijakan ini yang memberikan keleluasaan bagi pemerintah daerah untuk mengelola keuangan daerahnya seharusnya bisa meningkatkan kinerja keuangan daerah yang bersangkutan.

Indeks Kemampuan Keuangan (Bappenas:2003) terdiri atas: Rasio Kemandirian Keuangan Daerah, Rasio Derajat Desentralisasi Fiskal, Rasio Indeks Kemampuan Rutin, Rasio Keserasian dan Rasio Pertumbuhan Keuangan Pemerintah Daerah Kabupaten Sumba Barat tahun anggaran 2011 -2015, sehingga dapat diketahui bagaimana kecendurungan yang terjadi tiap tahunnya dalam kurun waktu lima tahun terakhir. Laporan Realisasi Anggaran (LRA) untuk tahun anggaran 2011 -2015 merupakan data yang digunakan yang nantinya akan diketahui bagaimana kinerja keuangan Kabupaten Sumba Barat selama lima tahun anggaran tersebut.

APBD merupakan rencana pelaksanaan semua pendapatan daerah dan semua belanja daerah dalam rangka pelaksanaan desentralisasi dalam tahun anggaran tertentu. Dengan demikian, pemungutan semua penerimaan daerah dalam rangka pelaksanaan desentralisasi bertujuan untuk memenuhi target yang ditetapkan dalam APBD. Laporan Realisasi Anggaran Kabupaten Sumba Barat merupakan laporan yang mengungkapkan kegiatan keuangan pemerintah Kabupaten yang menunjukkan ketaatan terhadap APBD. Laporan Realisasi Anggaran menyajikan ikhtisar sumber, aplikasi dan penggunaan sumber daya ekonomi yang dikelola oleh pemerintah Kabupaten dalam satu periode pelaporan. Dalam Peraturan Menteri Dalam Negeri Nomor 13 Tahun 2006 tentang Pedoman Pengelolaan Keuangan Daerah, disebutkan unsur yang dicakup dalam Laporan Realisasi Anggaran

Konsekuensi pembebanan tugas dan tanggung jawab ke daerah yang semakin besar, kepada daerah telah diserahkan sumber pendanaan yang terus meningkat 
secara signifikan dari tahun ke tahun, melalui skema transfer. Hal ini dapat dilihat berdasarkan hasil perhitungan sumber pendapatan dari pihak ekstern yaitu berupa bantuan dari pemerintah pusat atau provinsi ditambah dengan pinjaman.

Kemandirian keuangan daerah merupakan kemampuan pemerintah daerah dalam meningkatkan pendapatan asli daerah (PAD) seperti pajak daerah, retribusi dan lainlain. Oleh karena itu, otonomi daerah dan pembangunan daerah bisa diwujudkan hanya apabila disertai kemandirian keuangan yang efektif. Ini berarti bahwa pemerintahan daerah secara finansial harus bersifat independen terhadap pemerintah pusat dengan jalan sebanyak mungkin menggali sumber-sumber PAD seperti pajak, retribusi dan sebagainya serta mengoptimalkan sumber-sumber PAD yang telah ada.

Rumus yang digunakan untuk menghitung rasio ini adalah:

$$
\begin{aligned}
& \text { Rasio Kemandirian } \\
& =\frac{\text { Pendapatan Asli Daerah (PAD) }}{\text { Bantuan Pemerintah Pusat/Provinsi }+ \text { Pinjaman }} \times 100 \%
\end{aligned}
$$

Nordiawan (2008:48) mengemukakan bahwa Dana Perimbangan adalah dana yang bersumber dari pendapatan APBN yang dialokasikan kepada daerah untuk mendanai kebutuhan daerah dalam rangka pelaksanaan desentralisasi. Latar belakang lain adanya transfer dana pusat ke daerah ini antara lain untuk mengatasi ketimpangan fiskal vertikal (antara pusat dan daerah), mengatasi ketimpangan fiskal horizontal, serta guna mencapai standar pelayanan untuk masyarakat.

Ketimpangan fiskal horizontal muncul akibat tidak seimbangannya kapasitas fiskal daerah dengan kebutuhan fiskalnya. Dengan kata lain, kemampuan daerah untuk menghasilkan pendapatan asli daerah tidak mampu menutupi kebutuhan belanja daerah. Sesuai dengan PP No 55 tahun 2005 pasal 2, "Dana perimbangan mencakup Dana Bagi Hasil, Dana Alokasi Umum, dan Dana Alokasi Khusus". Jumlah dana perimbangan ditetapkan setiap tahun dalam APBN.

Pembagian dana untuk daerah melalui bagi hasil berdasarkan daerah penghasil cenderung menimbulkan ketimpangan antar daerah dengan mempertimbangkan kebutuhan dan potensi daerah. Alokasi DAU bagi daerah yang potensi fiskalnya besar namun kebutuhan fiskalnya kecil akan memperoleh alokasi DAU yang relatif kecil. Sebaliknya daerah yang memiliki potensi fiskalnya kecil namun kebutuhan fiskalnya besar akan memperoleh alokasi DAU yang relatif besar. Dengan maksud melihat kemampuan APBD dalam membiayai kebutuhan-kebutuhan daerah dalam rangka pembangunan daerah yang dicerminkan dari penerimaan umum APBD dikurangi dengan belanja pegawai.

Ketimpangan ekonomi antara satu provinsi dengan provinsi lain tidak dapat dihindari dengan adanya desentralisasi fiskal. Disebabkan oleh minimnya sumber pajak dan Sumber Daya Alam yang kurang dapat digali oleh Pemerintah Daerah. Untuk menanggulangi ketimpangan tersebut, Pemerintah Pusat berinisiatif untuk memberikan subsidi berupa DAU kepada daerah. Bagi daerah yang tingkat kemiskinannya lebih tinggi, akan diberikan DAU lebih besar dibanding daerah yang kaya dan begitu juga sebaliknya.

Komponen Dana Alokasi Umum merupakan komponen penyumbang terbesar terhadap pendapatan dari pihak ekstern. Hal ini dipengaruhi oleh bobot daerah, yang dinilai berdasarkan indeks penduduk, indeks luas daerah, indeks harga bangunan, dan indaks kemiskinan relatif yang dikemudian dibagi 4 (empat) dan dikalikan dengan pengeluaran daerah rata-rata. Berbeda dengan pemberian Dana Alokasi Khusus (DAK) yang hanya mempertimbangkan untuk pembiayaan kebutuhan yang bersifat khusus.Komponen terbesar kedua adalah dana penyesuian. Dana penyesuaian adalah dana yang dialokasikan untuk membantu daerah dalam rangka melaksanakan kebijakan tertentu Pemerintah dan DPR sesuai peraturan perundangan, yang terdiri atas dana insentif daerah, Dana Tambahan Penghasilan Guru Pegawai Negeri Sipil Daerah (PNSD), dana-dana yang dialihkan dari Kementerian Pendidikan Nasional ke Transfer ke Daerah, berupa Tunjangan Profesi Guru dan Bantuan Operasional Sekolah (BOS), Dana Penyesuaian Infrastruktur Daerah, dan sebagainya. Perhitungan Rasio Kemandirian Keuangan Kabupaten Sumba Barat dapat dilihat pada lampiran Tabel 1.

\section{(Insert Tabel 1)}

Menurut hasil perhitungan dan Gambar 1 selama lima tahun terakhir rasio kemandirian keuangan daerah Kabupaten Sumba Barat secara keseluruhan maka dapat disimpulkan bahwa rasio kemandirian keuangan daerah selama lima tahun pada Kabupaten Sumba Barat memiliki rata-rata tingkat kemandirian masih rendah dan dalam kategori kemampuan keuangan kurang dengan pola hubungan instruktif yaitu peranan pemerintah pusat sangat dominan dari pada daerah. Hal ini 
dapat dilihat dari rasio kemandirian yang dihasilkan masih berkisar antara $0,00 \%$ $9,27 \%$. Rasio kemandirian yang masih rendah mengakibatkan kemampuan keuangan daerah Kabupaten Sumba Barat dalam membiayai pelaksanaan pemerintahan dan pembangunan masih sangat tergantung pada penerimaan dari pemerintah pusat.

Kemandirian keuangan daerah menjadi sangat penting, baik dari sisi pendapatan (revenue), maupun dari sisi pengeluaran (expenditure) agar Pemerintah Daerah memiliki kemampuan yang lebih kuat untuk mendesain dan melaksanakan kegiatankegiatan yang bersifat stimulan bagi peningkatan kesejahteraan rakyat sesuai dengan aspirasi dan karakteristik masyarakatnya masing-masing. Pemerintah Kabupaten Sumba Barat terus menerus menggiatkan upaya mengoptimalkan peningkatan pendapatan daerah, khususnya Pendapatan Asli Daerah (PAD), karena menajemen pemungutan PAD berada di dalam ranah kebijakan Pemerintah Daerah sendiri, berbeda dengan Dana Perimbangan yang kebijakannya merupakan domain Pemerintahan Pusat.

\section{(Insert Gambar 1)}

Pada Gambar 1 menunjukkan bahwa Rasio kemandirian yang masih rendah dapat disebabkan pada sumber penerimaan daerah dan dasar pengenaan biaya, tampaknya Pendapatan Asli Daerah masih belum dapat diandalkan bagi daerah untuk otonomi daerah, karena relatif rendahnya basis pajak/retribusi yang ada di daerah dan kurangnya pendapatan asli daerah yang dapat digali oleh pemerintah daerah. Hai ini dikarenakan sumber-sumber potensial untuk menambah Pendapatan Asli Daerah masih dikuasai oleh pemerintah pusat, sedangkan untuk basis pajak yang cukup besar masih dikelola oleh pemerintah pusat, yang di dalam pemungutan/pengenaannya berdasarkan undang-undang/peraturan pemerintah, dan daerah hanya menjalankan serta akan menerima bagian dalam bentuk dana perimbangan. Dana perimbangan itu sendiri terdiri dari: Bagi Hasil Pajak, Bagi Hasil Bukan Pajak/Sumber Daya Alam, Dana Alokasi Umum, Dana Alokasi Khusus, dan penerimaan lainnya.

$\begin{aligned} & \text { Untuk mengatasi hal tersebut, } \\ & \text { pemerintah daerah harus mampu }\end{aligned}$
mengoptimalkan penerimaan dari potensi
pendapatannya yang telah ada. Inisiatif dan
kemauan pemerintah daerah sangat

diperlukan dalam upaya meningkatkan PAD. Pemerintah daerah harus mencari alternatifalternatif yang memungkinkan untuk dapat mengatasi kekurangan pembiayaannya, dan hal ini memerlukan kreatifitas dari aparat pelaksana keuangan daerah untuk mencari sumber-sumber pembiayaan baru baik melalui program kerjasama pembiayaan dengan pihak swasta dan juga program peningkatan PAD misalnya pendirian BUMD sektor potensial maupun penyertaan modal keperusahaan daerah dengan mendapatkan imbalan berupa deviden.

Desentralisasi fiskal daerah menunjukkan seberapa besar ketergantungan pemerintah daerah terhadap pemerintah pusat dalam membiayai pembangunan. Untuk mengetahui seberapa besar tingkat ketergantungan tersebut maka dilakukan dengan menggunakan ukuran apa yang disebut Derajat Desentralisasi Fiskal.

Rasio Derajat Desentralisasi Fiskal dapat dihitung dengan menggunakan rumus sebagai berikut:

$$
D D F=\frac{P A D t}{T P D t} \times 100 \%
$$

Dimana: DDF = Derajat Desentralisasi Fiskal

PADt $=$ Total PAD tahun $\mathrm{t}$

TPDt = total Penerimaan Daerah tahun $\mathrm{t}$

\section{(Insert Tabel 2)}

Kemampuan keuangan daerah Kabupaten Sumba Barat berdasarkan hasil perhitungan rasio derajat desentralisasi fiskal pada Tabel 2 menunjukkan masih kurangnya penerimaan yang diperoleh berdasarkan pendapatan asli daerah apabila dibandingkan dengan Total Pendapatan Daerah (TPD). Hal ini dapat dilihat pada kemampuan keuangan berdasarkan rasio derajat desentraslisasi fiskal pada tahun 2011 -2015 masih kurang, karena msih berada pada interval 5,26\% - 9,86\%. Berdasarkan jumlah rata-rata rasio derajat desentralisasi fiskal, kemampuan keuangan Kabupaten Sumba Barat masih berada pada tingkat kemampuan yang kurang, yaitu sebesar $6,97 \%$ dan berada pada kisaran $5,26 \%-9,86 \%$.

\section{(Insert Gambar 2)}

Rendahnya perolehan persentase yang dimiliki oleh Kabupaten Sumba Barat menunjukkan bahwa pemerintah Kabupaten belum mampu membiayai pengeluarannya 
sendiri dengan kata lain, masih sangat tergantung pada pemerintah pusat. Apabila hasil dari rasio derajat desentralisasi fiskal ini dipadukan dengan hasil perhitungan rasio kemandirian, maka akan terlihat jelas bahwa konstribusi PAD terhadap total pendapatan daerah secara keseluruhan masih relatif kecil, maka kinerja keuangan daerah dinilai masih sangat rendah (lihat Gambar 2).

Kemandirian fiskal daerah merupakan salah satu aspek yang sangat penting dari otonomi daerah secara keseluruhan. Manfaat dari kemandirian adalah mendorong peningkatan partisipasi prakarsa dan kreativitas masyarakat dalam pembangunan serta akan mendorong pemerataan hasil-hasil pembangunan (keadilan) di seluruh daerah dengan memanfaatkan sumber daya serta potensi yang tersedia di daerah.

Dari hal tersebut diatas kemandirian fiskal daerah menggambarkan kemampuan pemerintah daerah dalam meningkatkan Pendapatan Asli Daerah (PAD) seperti pajak daerah, retribusi dan lain-lain. Karena itu otonomi daerah dan pembangunan daerah bisa diwujudkan hanya apabila disertai kemandirian fiskal yang efektif. Ini berarti bahwa pemerintahan daerah secara finansial harus bersifat independen terhadap pemerintah pusat dengan jalan sebanyak mungkin menggali sumber-sumber PAD seperti pajak, retribusi dan sebagainya.

Indeks Kemampuan Rutin (IKR) dapat dihitung dengan menggunakan rumus sebagai berikut:

$$
I K R=\frac{P A D}{\text { Total Pengeluaran Rutin }} \times 100 \%
$$

Dalam penelitian ini, pengeluaran rutin atau belanja rutin diperoleh dari bagian belanja operasi. Hal ini dikarenakan adanya perubahan peraturan mengenai kelompok belanja dalam Peraturan Menteri Dalam Negeri Nomor 13 Tahun 2006 yang kemudian diubah kedalam Peraturan Menteri Dalam Negeri Nomor 59 Tahun 2011 tentang Pedoman Pengelolaan Keuangan Daerah. Berikut adalah rincian komponen pengeluaran/belanja rutin Kabupaten Sumba Barat. Dalam Permendagri Nomor 59 Tahun 2011 tentang Perubahan Atas Permendagri No.13 tahun 2006 tentang Pedoman Pengelolaan Keuangan Daerah diungkapkan pengertian belanja daerah, yaitu "belanja daerah adalah kewajiban pemerintah daerah yang diakui sebagian pengurang nilai kekayaan bersih". Dari pengertian tersebut, maka dapat disimpulkan bahwa belanja daerah adalah semua pengeluaran pemerintah daerah pada suatu periode anggaran yang berupa arus kas aktiva keluar.

Dengan telah diberikannya wewenang untuk mengelola keuangan daerah, maka Belanja Rutin diprioritaskan pada optimalisasi fungsi dan tugas rutin perangkat daerah, termasuk perangkat dinas-dinas yang telah dan akan dilimpahkan kepada Pemerintah Daerah. Komponen terbesar dari pengeluaran rutin Kabupaten Sumba Barat tahun anggaran 2011 -2015 adalah Belanja Pegawai. Dimana, belanja pegawai mengalami peningkatan secara signifikan. Kecenderungan di setiap SKPD atau satuan kerja lebih memperbanyak kegiatan. Dari kegiatan tersebut terdapat honor sehingga menyebabkan pemerintah Kabupaten menghabiskan anggaran lebih banyak untuk belanja pegawai daripada belanja pembangunan atau belanja modal dikarenakan hal itu.

Kemampuan daerah dalam membiayai pembangunan masih sering mengalami kendala berupa rendahnya kemampuan daerah dalam meningkatkan PADnya. Indikator rendahnya kemampuan daerah ini dapat dilihat dari Indeks Kemampuan Rutin (IKR) daerah, yang diperoleh dari besarnya perubahan PAD terhadap pengeluaran rutin daerah dalam persentase tahun yang sama.

Dari tabel 3, dapat disimpulkan bahwa Indeks Kemampuan Rutin selama lima tahun pada pemerintahan Kabupaten Sumba Barat masih dalam skala yang kurang, karena masih berada dalam skala interval antara 20,01\% $40,00 \%$ yaitu sebesar $24,99 \%$ (rata-rata IKR) dan ini berarti bahwa Pendapatan Asli Daerah (PAD) mempunyai kemampuan yang kurang untuk membiayai pengeluaran rutin, hal ini terjadi karena PAD Kabupaten Sumba Barat sangat kecil jika dibandingkan dengan nilai belanja rutin, dan selama ini lebih banyak tergantung pada sumber keuangan yang berasal dari pemerintah pusat.

\section{(Insert Tabel 3 dan Gambar 3)}

Berdasarkan Gambar 3, maka terlihat bahwa terjadi penurunan indeks kemampuan rutin pada tahun 2011 yang kemudian terus meningkat sampai dengan tahun 2015. Namun, walaupun trendnya terus mengalami peningkatan, kemampuan keuangan daerah Kabupaten Sumba Barat masih dinilai kurang. Penerimaan PAD yang tiap tahunnya meningkat, namun faktanya hal ini belum mampu menutupi belanja rutin yang ada. "Trend PAD terus meningkat, meskipun sesungguhnya pemeritah Kabupaten Sumba Barat belum mampu secara penuh dari PAD untuk menutup seluruh belanja daerah. 
Penyerahan otonomi tidak lepas dari kemampuan daerah dalam mengelola dan menggali sumber-sumber pendapatan daerah itu sendiri, baik yang bersumber dari Pendapatan Asli Daerah, Dana Perimbangan, serta penerimaan sumbangan dan bantuan lainnya. Pembinaan sumber-sumber pendapatan daerah selalu diupayakan dengan menggali potensi serta senantiasa mengadakan pengawasan terhadap sumbersumber pendapatan daerah yang ada. Setiap Negara dengan wilayah yang luas membutuhkan suatu sistem Pemerintahan daerah yang efektif. Sistem ini diperlukan tidak saja sebagai alat untuk melaksanakan berbagai program Pemerintah di daerah, tetapi juga alat bagi masyarakat setempat agar dapat berperan serta dalam menentukan prioritas untuk pembangunan daerahnya sendiri.

Oleh karena itu Pemerintah Daerah Kabupaten Sumba Barat berupaya meningkatkan penerimaan Pendapatan Asli Daerah yang bersumber dari berbagai sektor seperti hasil dari pajak daerah, retribusi daerah, hasil perusahaan milik daerah dan hasil pengelolaan kekayaan daerah serta lainlain pendapatan asli daerah yang sah. Dengan demikian meningkatnya Pendapatan Asli Daerah dapat memberikan indikasi yang lebih baik bagi kemampuan keuangan daerah dalam mengatur dan mengurus rumah tangganya sendiri terutama dalam pelaksanaan tugas- tugas pelayanan kepada masyarakat serta percepatan dan peningkatan pembangunan dalam segala bidang di daerahnya masing-masing.

Meskipun terdiri dari empat sumber, hingga saat ini hanya Pajak Daerah dan Retribusi Daerah yang menyumbang secara siginifkan terhadap total penerimaan PAD suatu Daerah. Sementara sumber yang berasal dari BUMD dan Lain PAD yang sah masih belum berperan. Komponen terbesar dalam penerimaan PAD Kabupaten Sumba Barat adalah pajak daerah. Kabupaten Sumba Barat sendiri memiliki 10 (sepuluh) jenis pajak daerah. Walaupun jumlah jenis pajak tergolong banyak, tapi pengelolaannya belum maksimal.

Intensifikasi adalah upaya peningkatan PAD melalui proses optimalisasi pengelolaan sumber-sumber pendapatan daerah yang selama ini telah dikelola oleh pemerintah daerah. Pada tahun 2015, intensifikasi pengelolaan PAD meliputi:

a. Peningkatan kualitas pelayanan, antara lain melalui peningkatan dan pengembangan pelayanan Samsat Unggulan, pemanfaatan teknologi informasi dalam pelayanan Pajak Daerah dan sistem pelaporan Pajak Daerah, dan penyederhanaan sistem dan prosedur pelayanan Pajak Daerah dan Retribusi Daerah.

b. Peningkatan sarana dan prasarana, antara lain melalui renovasi dan pengembangan kantor dan sarana pelayanan untuk meningkatkan kenyamanan masyarakat dalam membayar Pajak dan Retribusi Daerah.

c. Peningkatan kualitas SDM, melalui pelatihan maupun bimbingan teknis tentang pengelolaan pendapatan daerah.

d. Peningkatan tertib administrasi pemungutan Pajak Daerah dan Retribusi Daerah pada seluruh SKPD pengelola PAD.

e. Koordinasi yang intensif dan efektif, yaitu dengan meningkatkan kerjasama dengan seluruh SKPD pengelola pendapatan, termasuk dengan instansi vertikal dalam hal intensifikasi Dana Bagi Hasil dan Pendapatan Lain-Lain yang Sah.

f. Peningkatan ketaatan masyarakat dalam memenuhi kewajibanya membayar Pajak Daerah melalui sosialisasi, peningkatan pengawasan dan penegakan sanksi.

\section{Sumber-Sumber Pendapatan Asli Daerah Kabupaten Sumba Barat}

Sumber-sumber Pendapatan Asli Daerah (PAD) Kabupaten Sumba Barat, terdiri dari:

1. Pajak Daerah, yaitu terbagi atas:

Pajak Hotel, Pajak Restoran, Pajak Hiburan, Pajak Reklame, Pajak Penerangan Jalan, Pajak Galian Golongan, Pajak Parkir, Pajak Air Bawah Tanah, Pajak BPHTB

2. Retribusi Daerah, antara lain:

Retribusi Pelayanan Kesehatan, Retribusi Pelayanan Kebersihan, Kartu Tanda Penduduk dan Akta Catatan Sipil, Retribusi Izin Mendirikan Bangunan, Retribusi Izin Gangguan (Surat Izin Tempat Usaha), Retribusi Izin Jasa Konstruksi.

3. Pendapatan Hasil Kekayaan Daerah Yang Dipisahkan, terdiri atas:

a. Bagian Laba Usaha Daerah:

1) Perusahaan Daerah Air Minum.

b. Laba Lembaga Keuangan Bank:

1) Bank BPD Sumba Barat

4. Lain-Lain Pendapatan Asli Daerah Yang Sah yang terdiri dari Hasil Penjualan Aset Daerah yang Tidak Dipisahkan, Jasa Giro, Lain-lain Pendapatan yang sah, 
Kompensasi atas Penyediaan Fasilitas Sosial dan Fasilitas Umum

\section{PENUTUP}

Dari hasil penelitian yang dilakukan dapat diambil kesimpulan bahwa tingkat kemampuan keuangan daerah Kabupaten Sumba Barat dalam pelaksanaan otonomi daerah tahun anggaran 2011 -2015 dianggap masih kurang. Hal ini dapat dilihat dari Rasio kemandirian keuangan daerah selama lima tahun terakhir yang menghasilkan jumlah rataratanya sebesar $6,8 \%$ dengan pola hubungan yang instruktif. Dari hasil tersebut, tergambar dengan jelas masih besarnya ketergantungan pemerintah Kabupaten Sumba Barat terhadap sumber-sumber dana bantuan dari pihak ekstern, baik dari pemerintah pusat maupu dari pemerintah provinsi.

Rasio Derajat Desentralisasi Fiskal, selama 5 (lima) tahun menunjukkan angka rata-rata sebesar $6,97 \%$ dengan kemampuan keuangan yang tergolong kurang. Hasil ini menunjukkan bahwa pemerintah Kabupaten Sumba Barat belum mampu membiayai pengeluarannya sendiri. Pemerintah Kabupaten Sumba Barat masih bergantung kepada pemerintah pusat dalam hal pembiayaan pengeluaran.

Berdasarkan kemampuan PAD untuk membiayai pengeluaran rutin daerah, yang sering disebut juga dengan Rasio IKR (Indeks Kemampuan Rutin) rata-rata hanya sebesar $7,28 \%$ dengan pola kemampuan keuangan yang masih berada dalam interval $5,16 \%$ $11,62 \%$ yang dinilai kurang. Artinya, PAD Kabupaten Sumba Barat belum mampu membiayai belanja rutin yang dilakukan oleh pemerintah Kabupaten .

Konstribusi Pendapatan Asli Daerah terhadap Anggaran Pendapatan dan Belanja Daerah Kabupaten Sumba Barat dalam menunjang pelaksanaan otonomi daerah tahun anggaran 2011 -2015 masih relatif kecil. Berdasarkan hasil perhitungan konstribusi $P A D$, hasil rata-rata yang diperoleh adalah sebesar 6,97\%. Artinya, rata konstribusi PAD terhadap APBD selama lima tahun hanya sebesar $6,97 \%$. Angka yang sangat rendah, namun merupakan angka tertinggi pencapaian konstribusi PAD. Rendahnya konstribusi PAD terhadap Total Pendapatan APBD, mengharuskan pemerintah Kabupaten lebih memperketat aturan yang ada, serta lebih lihai mencari sumber-sumber pendanaan alternatif. Salah satunya adalah pendirian Badan Usaha Milik Daerah (BUMD) sektor potensial yang berbentuk Perusahaan Daerah.

Pemerintah Kabupaten Sumba Barat harus berupaya peningkatan pendapatan daerah melalui optimalisasi pengelolaan pendapatan daerah sesuai potensi dan kewenangan yang ada berdasarkan ketentuan peraturan perundang-undangan yang berlaku, dengan tetap mengedepankan pertimbangan aspek keadilan dan kemampuan masyarakat. Optimalisasi pengelolaan pendapatan daerah dilakukan dengan mensinergikan program intensifikasi dan ekstensikasi sumber-sumber pendapatan daerah.

\section{DAFTAR PUSTAKA}

Ajhar, Mhd. Karya Satya, 2008. "Analisis Kinerja Keuangan Pemerintahan Daerah Kabupaten/Kabupaten Sebelum dan Setelah Otonomi Daerah", Tesis, Departemen Akuntansi Sekolah Pasca Sarjana Fakultas Ekonomi, Universitas Sumatera Utara, Medan.

Bastian, Indra, 2001. Manual Akuntansi Keuangan Pemerintahan Daerah, BPFE Yogyakarta.

, 2006. Akuntansi Sektor Publik, Erlangga, Yogyakarta.

,2006. Akuntansi Sektor Publik Edisi 2, Salemba Empat. Jakarta.

Erfa, Azhir, 2008. "Analisis Kinerja Keuangan Pemerintahan Daerah Setelah Otonomi Khusus (Studi Kasus Pada Pemerintahan Daerah Kabupaten Aceh Utara)", Skripsi, Departemen Akuntansi Fakultas Ekonomi Universitas Sumatera Utara, Medan.

Halim, Abdul,2002. Akuntansi Sektor Publik: Akuntansi Keuangan Daerah, Salemba Empat, Jakarta.

2004. Bunga Rampai Manajemen Keuangan Daerah Edisi Revisi, UPP UMP YKPN, Yogyakarta.

,2011. Akuntansi Keunagan Daerah, Salemba Empat, Jakarta.

Haryati, Sri, 2006. "Perbandingan Kinerja Keuangan Daerah Sebelum dan Sesudah Kebijakan Otonomi Daerah Kabupaten Sleman Tahun 1998-2000 dan 2000-2001", Skripsi, Departemen Akuntansi Fakultas Ekonomi, Universitas Islam Indonesia, Yogyakarta 


\section{Lampiran - lampiran :}

Tabel 1.

Perhitungan Rasio Kemandirian Keuangan Kabupaten Sumba Barat Tahun Anggaran 2011-2015

\begin{tabular}{|c|c|c|c|c|c|c|c|c|}
\hline No & TA & $\begin{array}{c}\text { Total Pendapatan } \\
\text { (Rp) }\end{array}$ & $\begin{array}{l}\text { Pendapatan Asli } \\
\text { Daerah (Rp) }\end{array}$ & $\%$ & $\begin{array}{c}\text { Bantuan Pemerintah } \\
\text { Pusat/Prov }+ \\
\text { Pinjaman (Rp) }\end{array}$ & $\%$ & $\begin{array}{c}\text { Rasio } \\
\text { Kema } \\
\text { ndiria } \\
\text { n }\end{array}$ & $\begin{array}{c}\text { Pola } \\
\text { Hubungan }\end{array}$ \\
\hline 1 & 2011 & $395.951 .780 .542,55$ & $\begin{array}{c}20.843 .737 .126,5 \\
5\end{array}$ & 5,26 & 375.108 .043 .398 .00 & 94,73 & 5,56 & Instruktif \\
\hline 2 & 2012 & $371.832 .066 .453,01$ & $\begin{array}{c}20.844 .670 .264,0 \\
1\end{array}$ & 5,60 & 350.987 .396 .189 .00 & 94,39 & 5,93 & Instruktif \\
\hline 3 & 2013 & $425.845 .702 .018,36$ & $\begin{array}{c}23.960 .648 .245,3 \\
8\end{array}$ & 6,44 & 401.885.053.773.00 & 94,37 & 5,96 & Instruktif \\
\hline 4 & 2014 & $480.743 .921 .606,52$ & $\begin{array}{l}32.649 .628 .297,5 \\
2\end{array}$ & 7,67 & 448.094.293.309.00 & 93,20 & 7,28 & Instruktif \\
\hline 5 & 2015 & $558.419 .635 .103,07$ & $\begin{array}{c}47.398 .743 .299,0 \\
7 \\
\end{array}$ & 9,86 & 511.020 .891 .804 .00 & 91,51 & 9,27 & Instruktif \\
\hline \multicolumn{3}{|c|}{ Rata-Rata } & 29.139.485.446 & 6,97 & $417.419 .135 .694,60$ & 93,64 & $6,8 \%$ & Instruktif \\
\hline
\end{tabular}

Sumber: Data diolah, 2017

Gambar 1.

Hasil Perhitungan Rasio Kemandirian Keuangan Kabupaten Sumba Barat Tahun Anggaran 2011 -2015

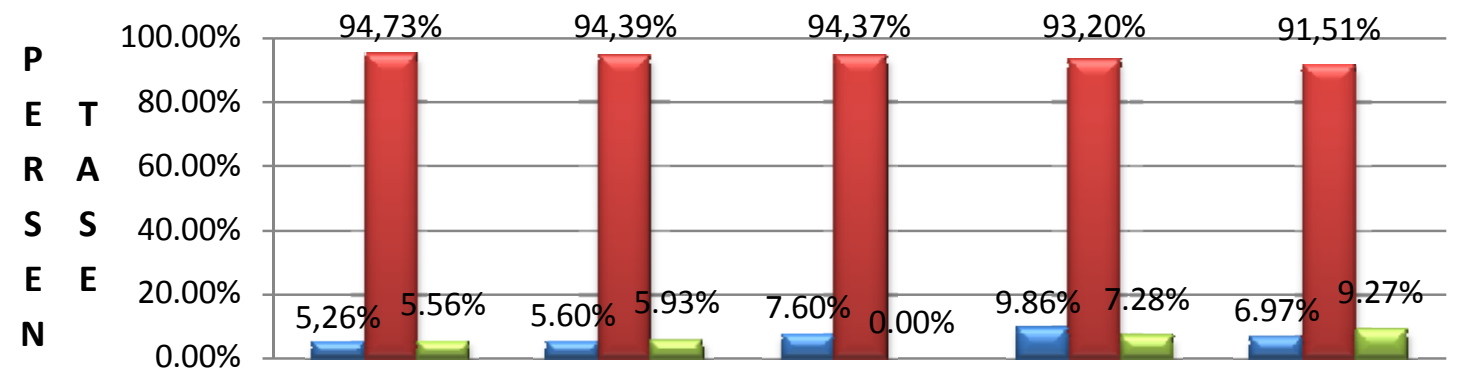

चPAD $₫$ Bantuan Pemerintah Pusat/Provinsi $\square$ Rasio Kemandirian

Tabel 2.

Perhitungan Rasio Derajat Desentralisasi Fiskal Kabupaten Sumba Barat Tahun Anggaran 2011-2015

\begin{tabular}{|c|c|c|c|c|}
\hline $\begin{array}{c}\text { Tahun } \\
\text { Anggaran }\end{array}$ & $\begin{array}{l}\text { PAD } \\
\text { (Rp) }\end{array}$ & $\begin{array}{l}\text { TPD } \\
\text { (Rp) }\end{array}$ & $\%$ & $\begin{array}{c}\text { Kemampuan } \\
\text { Keuangan }\end{array}$ \\
\hline 2011 & $20.843 .737 .126,55$ & $395.951 .780 .542,55$ & 5,26 & Kurang \\
\hline 2012 & $20.844 .670 .264,01$ & $371.832 .066 .453,01$ & 5,60 & Kurang \\
\hline 2013 & $23.960 .648 .245,38$ & $425.845 .702 .018,36$ & 6,44 & Kurang \\
\hline 2014 & $32.649 .628 .297,52$ & $480.743 .921 .606,52$ & 7,67 & Kurang \\
\hline 2015 & $47.398 .743 .299,07$ & $558.419 .635 .103,07$ & 9,86 & Kurang \\
\hline \multicolumn{3}{|c|}{ Rata-rata } & 6,97 & Kurang \\
\hline
\end{tabular}

Sumber: Data diolah, 2017 


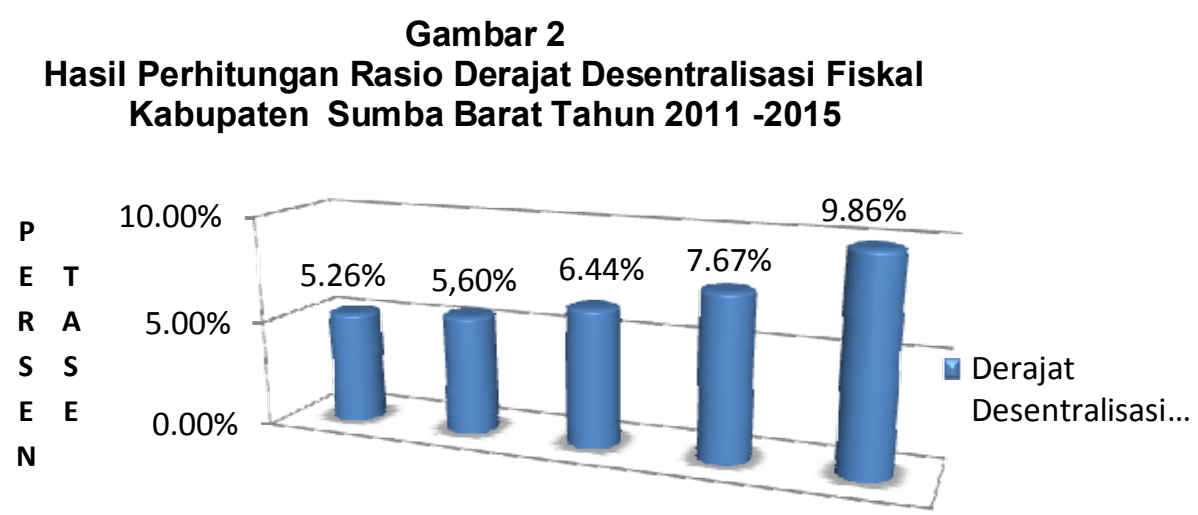

Tabel 3

Perhitungan Rasio Indeks Kemampuan Rutin

Kabupaten Sumba Barat Tahun 2011 -2015

\begin{tabular}{|c|c|c|c|c|}
\hline $\begin{array}{c}\text { Tahun } \\
\text { Anggaran }\end{array}$ & PAD (Rp) & $\begin{array}{c}\text { Pengeluaran Rutin } \\
\text { (Rp) }\end{array}$ & $\%$ & $\begin{array}{c}\text { Kemampuan } \\
\text { Keuangan }\end{array}$ \\
\hline 2011 & $20.843 .737 .126,55$ & 403.595 .002 .366 & 5,16 & Kurang \\
\hline 2012 & $20.844 .670 .264,01$ & 373.338 .908 .284 & 5,58 & Kurang \\
\hline 2013 & $23.960 .648 .245,38$ & 396.034.313.392 & 6,05 & Kurang \\
\hline 2014 & $32.649 .628 .297,52$ & 407.868 .223 .650 & 8,01 & Kurang \\
\hline 2015 & $47.398 .743 .299,07$ & 522.402 .848 .942 & 11,62 & Kurang \\
\hline \multicolumn{3}{|c|}{ Rata-rata } & 7,28 & Kurang \\
\hline
\end{tabular}

Sumber: Data diolah, 2017

Gambar 3

Hasil Perhitungan Indeks Kemampuan Rutin Kabupaten Sumba Barat Tahun Anggaran 2011 -2015

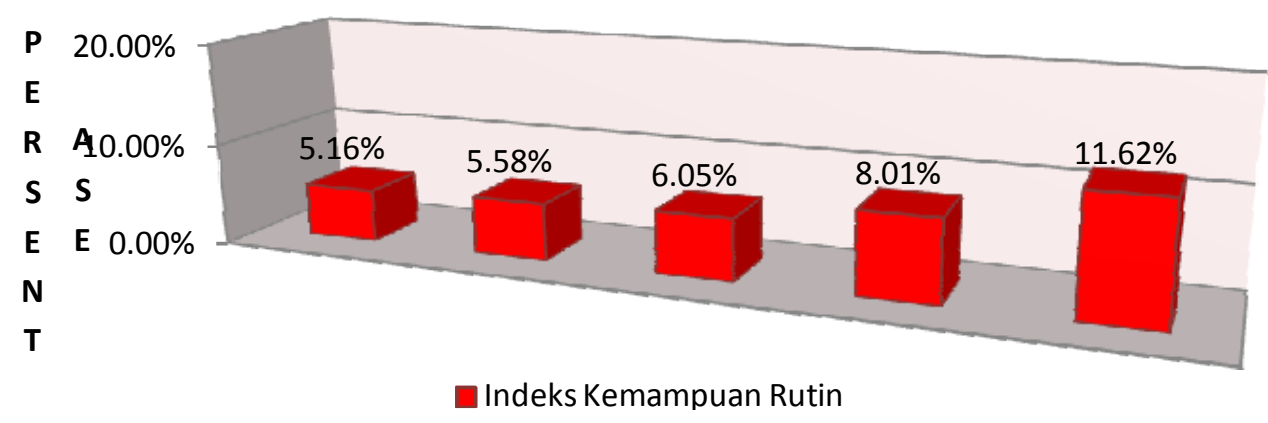

